IN MEMORIAM

\title{
IN MEMORIAM José Miguel Cañive, MD
}

Javier I. Escobar ${ }^{1 凶}$

(c) The Author(s), under exclusive licence to American College of Neuropsychopharmacology 2021

Neuropsychopharmacology (2022) 47:613; https://doi.org/10.1038/s41386-021-01206-z

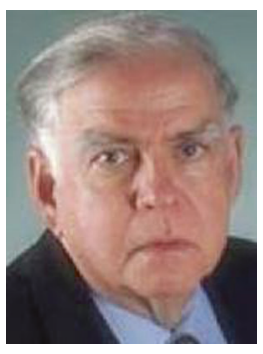

José was born in La Habana, Cuba, on July 26, 1941. He left his native land shortly after Fidel Castro came to power and immigrated to Spain to study medicine. He received his medical degree from Complutense University in Madrid, Spain, in 1966. Next, he came to the United States for an internship in New York City and then went to Canada to do his psychiatric residency training at Mc Gill University that he started in 1972. Following completion of his residency, Jose worked briefly as a clinical psychiatrist in British Columbia and then went to Albuquerque, New Mexico, to join the University of New Mexico (UNM) Medical School in 1978. At UNM he went from Assistant to full Professor of Psychiatry and Neurosciences. He was director of the outpatient aftercare division at the UNM Mental Health Center where he gradually initiated his clinical research career. Following the urging of our common mentor, the late Vicente (Vic) Tuason, Jose next moved to the Raymond G. Murphy VA Medical Center, Albuquerque New Mexico, where his research career fully blossomed. At the VA he became director of psychiatry research and led a most successful research operation until his retirement in 2019. At the VA, his research was at first focused on clinical psychopharmacology. He was Principal
Investigator for several VA Cooperative Studies Program studies and participated in NIMH collaborative trials, such as the Clinical Antipsychotic Trials of Intervention Effectiveness (CATIE). Jose's research made important contributions to our understanding of schizophrenia and post-traumatic stress disorders. One of his unique research contributions was the systematic study of auditory processing in schizophrenia with magnetoencephalography (MEG) for which he received ongoing research support from $\mathrm{NIH}$. Jose was an outstanding mentor, particularly for Hispanic psychiatrists, many of whom entered successful research careers.

José was truly a global citizen who spoke several languages and enjoyed world travel. He attained significant national and international reputation and received many awards and honors. He was a highly skilled pianist, a superb interpreter of classical Cuban "boleros", reminiscent of his friend and compatriot, the famed Enrique Chía. We often travelled together and more specially, played, and sang together old Latin "boleros" in numerous venues. I will miss him dearly!

He was accepted for ACNP membership in 2010 and subsequently became a Fellow in 2016.

José was President of the American Society of Hispanic Psychiatry (ASHP) in 1998 and received the Simon Bolivar Award, from the American Psychiatric Association (APA), the highest honor conferred to Hispanic scholars, in 2008.

He was naturalized in the United States, and more recently he became a Spanish citizen and moved his home (and piano) to Madrid, to an apartment in the legendary "Paseo Rosales" where he spent the last 2 years of his life. I saw him there and heard him play the piano for the last time in 2020. He died after a short illness in June 2021. He leaves his wife Polly, his sons Claudio, Paco and Nick and several grandchildren.

${ }^{1}$ Associate Dean for Global Health, Rutgers-Robert Wood Johnson Medical School, New Brunswick, NJ, USA. ${ }^{凶}$ email: escobaja@rwjms.rutgers.edu

Received: 5 October 2021 Accepted: 5 October 2021

Published online: 28 October 2021 